\title{
Temperatura y precipitación de los sitios de colecta de variedades nativas de frijol ayocote (Phaseolus coccineus $\mathrm{L})$.
}

\author{
Temperature and precipitation from collections site of native \\ varieties of runner bean (Phaseolus coccineus L.)
}

\begin{abstract}
Ma. Luisa Patricia Vargas Vázquez ${ }^{1}$, José Socorro Muruaga Martínez ${ }^{1}$ Alfredo Pérez Guerrero²
${ }^{1}$ Campo Experimental Valle de México- INIFAP. Carretera Los Reyes-Texcoco km 13.5, Coatlinchán, Estado de México. C. P. 56250. Tel. 01 595 921-26-57. Ext. 176. (ymuruaga@hotmail.com). ${ }^{2}$ Colegio de Postgraduados, carretera México-Texcoco, km. 36.5. Montecillo, Texcoco, Estado de México. C. P. 56230. Tel. 595952 02 00. (pg.alfred@gmail.com). ${ }^{\S}$ Autora para correspondencia: patricia_vargas_mx@yahoo.com.
\end{abstract}

\section{Resumen}

La conservación y regeneración de semilla de la colección de frijol ayocote del banco de germoplasma del INIFAP requiere conocer el clima de los sitios de domesticación de la especie. En 2010, en el Campo Experimental Valle de México, se registraron los datos de pasaporte, localidad, estado, altitud, coordenadas geográficas, precipitación, y temperatura mínima y máxima media anual de dichos sitios. Para ello se utilizaron datos y mapas de García y CONABIO (1998) escala 1:1000000; el "software" SIG ARC-INFO, versión 8.0 y el "hardware" SPARCstation, SUN OS, versión 5.5.1 del laboratorio de Sistemas de Información Geográfica del instituto. Las 798 accesiones de la colección se domesticaron en 140 sitios de 13 estados del territorio nacional, $80 \%$ en altitudes de 1500 a $2500 \mathrm{msnm}$ precipitación de 500 a $1000 \mathrm{~mm}$ anuales. El amplio rango de temperatura mínima y temperatura máxima separó los sitios en: muy fríos, de -5 a $1{ }^{\circ} \mathrm{C}$ en la noche y de 21 a $31^{\circ} \mathrm{C}$ en el día; fríos de 3 a $5^{\circ} \mathrm{C}$ en la noche y de 25 a $33^{\circ} \mathrm{C}$ en el día; y semifríos de 6 a $9{ }^{\circ} \mathrm{C}$ en la noche y de 25 a $37^{\circ} \mathrm{C}$ en el día. La distribución de variedades criollas de la especie se concentra sobre todo en zonas altas y húmedas del territorio nacional, aunque también se adapta a zonas semiáridas con poca precipitación y muy cálidas.

\section{Abstract}

The conservation and regeneration of seed collection of runner bean of the germplasm bank from INIFAP requires knowing the weather sites of domestication of the species. In 2010, at the Experimental Station of Valle de Mexico, were registered the passport data, locality, state, altitude, geographical coordinates, precipitation, minimum and maximum temperature and annual average of such sites. For this data and maps from Garcia and CONABIO were used (1998) 1:1 000000 scale, the "software" GIS ARCINFO, version 8.0 and the "hardware" SPARCstation, SUNOS, Version 5.5.1 from the Laboratory of Geographic Information Systems from INIFAP. The 798 accessions in the collection were domesticated in 140 sites in 13 states of the country, $80 \%$ at altitudes from 1500 to 2500 masl, precipitation from 500 to $1000 \mathrm{~mm}$ annually. The wide range of minimum and maximum temperature separated sites into: very cold, -5 to $-1{ }^{\circ} \mathrm{C}$ at night and 21 to $31{ }^{\circ} \mathrm{C}$ during the day, cold 3 to $5{ }^{\circ} \mathrm{C}$ at night and 25 to $33{ }^{\circ} \mathrm{C}$ during the day, and semi cold 6 to $9{ }^{\circ} \mathrm{C}$ at night and 25 to $37^{\circ} \mathrm{C}$ in the day. The distribution of native varieties of the species are concentrated in high and humid areas of the country, but also adapted to semi-arid with little rainfall and very warm.

\footnotetext{
* Recibido: enero de 2013 
Palabras clave: Phaseolus spp., bancos de germoplasma, biogeografía.

\section{Introducción}

La colección de frijol ayocote Phaseolus coccineus L. del banco de germoplasma del Instituto Nacional de Investigaciones Forestales, Agrícolas y Pecuarias (INIFAP), consta de 798 accesiones colectadas principalmente de la zona central del territorio mexicano en la década de los años 60 del siglo XX. En la actualidad es necesario conocer el clima de los sitios de domesticación de la especie para complementar sus datos de pasaporte y facilitar la regeneración de la semilla resguardada.

Éste trabajo registra la ocurrencia de precipitación y temperaturas mínima media anual y máxima media anual en dichos sitios. La diversidad de climas en el territorio mexicano se debe a: su situación geográfica dentro de la zona de transición entre las áreas templadas y tropicales del planeta, al dominio de diversos sistemas de viento, su gran extensión en latitud, su situación entre dos grandes océanos, pero sobre todo por su gran variación en altitud que originan contrastes climáticos notables en distancias cortas debido a que las grandes sierras actúan como barreras climáticas que modifican la cantidad de lluvia y temperaturas, lo cual origina que dentro de una misma región puedan encontrarse distintos grados de humedad y temperatura (Vidal, 2005). La Sierra Madre Occidental establece un puente de clima húmedo entre las zonas tropical y templada el cual junto con el puente climático de la vertiente del golfo, constituyen dos pasos esenciales para la difusión de las especies vegetales así como para los contactos entre civilizaciones (Bataillon, 1993).

El frijol ayocote como se le nombra en el centro de México del mex. Ayecotli, frijol mucho más grueso que el común (Santamaría, 2005) recibe otros nombres como frijolillo en Hidalgo (probablemente forma silvestre), frijol de risa y yexixima en Tlaxcala, frijolón en Querétaro, frijol cubinche en San Luís Potosí, shut chenek en Chiapas, shashan en Veracruz y kumat en Guatemala (Debouck, 2000). Está ampliamente distribuido en el Valle de México, entre 2300 y $3000 \mathrm{~m}$ de altitud en sitios con pastizal, matorral o bosque de pino y encino (Rzedowski y Rzedowski 2001).
Key words: Phaseolus spp., germplasm bank, biogeography.

\section{Introduction}

The collection of runner bean Phaseolus coccineus L. from the germplasm bank of the National Institute for Forestry, Agriculture and Livestock (INIFAP), consists of 798 accessions collected mainly from the central area of Mexico in the early 60 s of the twentieth century. At present it is necessary to know the climate of the sites of domestication of the species to complement their passport data and facilitate the regeneration of seed.

This work records the occurrence of precipitation and annual average minimum temperatures and maximum annual average on such sites. The diversity of climates in the Mexican territory is due to: its geographical location within the transition zone between temperate and tropical areas of the planet, to the domain of various wind systems, its extension in latitude, its location between two major oceans, but above all for their great variation in altitude that cause significant climatic contrasts over short distances because the big mountains act as weather barriers that modify the amount of rainfall and temperature, which causes that within the same region can be different degrees of humidity and temperature (Vidal, 2005). The Sierra Madre Occidental establishes a bridge of the humid climate between tropical and temperate zones, which together with the climate bridge of the gulf side, are two essential steps for the dissemination of plant species as well as contacts between civilizations (Bataillon, 1993).

The runner bean as they are named in the center of Mexico's from mex. Ayecotli, beans much thicker than ordinary (Santamaría, 2005) receives other names like frijolillo in Hidalgo (probably the wild), laughter bean and yexixima bean in Tlaxcala, frijolon in Querétaro, cubinche bean in San Luis Potosí, shut Chenek in Chiapas, shashan in Veracruz and Kumat in Guatemala (Debouck, 2000). It is widely distributed in the Valley of Mexico, between 2 300 and $3000 \mathrm{~m}$ of altitude in grassland, scrub or pine-oak forest sites (Rzedowski and Rzedowski 2001).

In the 90s, Debouck (1994) indicates that the runner bean was domesticated in the highlands of Mexico and then indicates that the wild runner bean grows in places from 
En la década de los 90, Debouck (1994) señala que el frijol ayocote fue domesticado en las zonas altas y húmedas de México y después indica que el frijol ayocote silvestre crece en sitios desde 1400 a 2800 msnm en bosques húmedos de altura desde Chihuahua, México hasta Panamá, y que al igual que P.polyanthus soporta precipitaciones mayores que otras especies desde 400 hasta $2600 \mathrm{~mm}$ al año siempre y cuando el suelo tenga buen drenaje (Debouck, 1997).

La forma cultivada de P. coccineus con frecuencia es anual, pero puede sobrevivir muchos años en el campo debido a su engrosada raíz carnosa o bien en lugares donde se favorezca su crecimiento. Estos cultivares son altamente variados con semillas de muchos colores y patrones de moteado, en tanto que las formas silvestres de una sola localidad es menos variable (Debouck, 2000).

La gama de temperaturas en que crecen las plantas varía según la especie, las plantas árticas y alpinas prosperan en un ambiente de temperatura de 0 a $10^{\circ} \mathrm{C}$; las especies de la zona templada crecen entre 5 y $45^{\circ} \mathrm{C}$, mientras que las tropicales están adaptadas a una variación de temperatura de 10 a 45 ${ }^{\circ} \mathrm{C}$. Además, las raíces tienen una temperatura óptima para el crecimiento más baja que la parte aérea o vástago de la planta (Miller, 1967) y como la temperatura del suelo es diferente de la del aire, las plantas deben tener diferentes temperaturas cardinales (mínima, máxima yóptima) para raíces y vástagos. Además, existe una inducción de las bajas temperaturas a órganos de almacenamiento subterráneos como tubérculos y bulbos, por ejemplo en papa la formación de tubérculos ocurre cuando la temperatura de la noche baja de $20{ }^{\circ} \mathrm{C}$ (Salisbury y Ross, 1985).

Las plantas de frijol ayocote pueden tener un ciclo anual o perenne, y es muy posible que la perennidad esté dada por su raíz carnosa, y a cual no debe ser considerada como un tubérculo. En la actualidad no existen estudios que señalen cuál es el factor que impulsa el desarrollo o formación de la raíz carnosa en la planta de ayocote, y tampoco se ha diferenciado material basándose en dicho carácter. En cuanto a la perennidad del ayocote, Hernández, et al. (1979) señalan que como planta anual se siembra en monocultivo o intercalado con maíz. Las plantas que se intercalan con maíz pueden ser de guías cortas (en climas sub-húmedos con lluvias en el verano y con heladas durante el invierno), o plantas trepadoras que maduran mucho después que el maíz (en climas calientes y subhúmedos con lluvias en el verano y en áreas libres de heladas). Como planta perenne
1400 to 2800 masl in rainforests of heights from Chihuahua, Mexico to Panamá, and that same as P. polyanthus supports higher precipitations than other species from 400 to 2 $600 \mathrm{~mm}$ per year as long as the soil has a good drainage (Debouck, 1997).

The cultivated form of $P$. coccineus is often annual, but can survive for many years in the field due to their thickened fleshy root or in places where it promotes growth. These cultivars are highly varied with seeds of many colors and mottled patterns; while wild forms of one location is less variable (Debouck, 2000).

The temperature range in which plants grow varies by species, arctic and alpine plants thrive in an ambient temperature of 0 to $10^{\circ} \mathrm{C}$; species of the temperate zone grow between 5 and $45^{\circ} \mathrm{C}$, while tropical are adapted to a temperature variation of 10 to $45^{\circ} \mathrm{C}$. Besides, the roots have an optimal temperature for growth lower than the aerial or stem part of the plant (Miller, 1967) and as the soil temperature is different from that of air, the plants must have different cardinal temperatures (minimum, maximum and optimum) for roots and stem. In addition, there is an induction of low temperature to underground storage organs such as tubers and bulbs, for example in potato the tuber formation occurs when the temperature at night is below 20 ${ }^{\circ} \mathrm{C}$ (Salisbury and Ross, 1985).

Runner bean plants can be annual or perennial cycle, and it is possible that the continuity is given by its fleshy root, and which should not be considered as a tuber. At present there are no studies indicating what is the factor that drives the development or fleshy root formation in runner bean plant and neither has not been differentiated material based on such trait. As for the durability of runner bean, Hernández et al. (1979) point out that as an annual plant is cultivated in monoculture or intercropped with maize. Plants that are intercropped with corn can be short guides (in sub-humid climates with rains in the summer and frost in winter), or vine plants that mature much later than maize (in hot and sub humid climates with rainfall in summer and frost free areas). As a perennial plant the first year is planted with maize and the second as a monoculture, or again associated with maize or fruit trees.

Miranda (1978) noted that temperature is one of the ecological factors that have limited the dispersal of populations of $P$. coccineus. Recent studies in runner bean of the physiographic sub province of Carso Huasteco show 
se siembra el primer año asociado con maíz y el segundo como monocultivo, o de nuevo asociado con maíz o con árboles frutales.

Miranda (1978) señaló que la temperatura es uno de los factores ecológicos que ha limitado la dispersión de las poblaciones de $P$. coccineus. Estudios recientes de los ayocotes de la subprovincia fisiográfica Carso Huasteco muestran el efecto de la temperatura de su sitio de origen en la fenología de la planta. Las plantas que al cultivarse en Chapingo a inicios de julio, tuvieron ciclo corto (100100 días), fueron colectadas en sitios muy fríos donde la temperatura mínima media anual puede bajar hasta $-2{ }^{\circ} \mathrm{C}, \mathrm{y}$ los más tardíos (110-120 días) en sitios donde la temperatura mínima media anual sube de 2 a $4{ }^{\circ} \mathrm{C}$ (Vargas et al., 2011).

Cada especie tiene en su ciclo de vida una temperatura mínima debajo de la cual no crece, una temperatura óptima en la cual crece a su tasa máxima, y una temperatura máxima por encima de la cual no crecerá e incluso morirá. La planta de frijol común puede soportar temperaturas extremas entre 5 y $40^{\circ} \mathrm{C}$ (Masaya y White, 1991). Como en el frijol ayocote no se conocen estos datos y solo se ha indicado que es una especie adaptada a climas templados, a continuación se pretende hacer una clasificación de sitios de colecta de 798 variedades nativas de acuerdo a la ocurrencia de temperatura mínima y máxima en dichos ambientes. Se utiliza la temperatura mínima media anual y la máxima media anual sin puntualizar los meses o estaciones del año debido a la diversidad de ambientes que a su vez origina un gran número datos a analizar. Así solo hacemos el primer acercamiento al conocimiento de la temperatura ambiental en los sitios donde campesinos de al menos 10 generaciones anteriores a la nuestra, han mejorado los ayocotes por selección empírica.

\section{Materiales y métodos}

Se determinó la localidad y municipio, estado o entidad federativa, altitud, precipitación total anual, temperatura mínima media anual y temperatura máxima media anual de los sitios de colecta de 978 accesiones de la forma cultivada de frijol ayocote (variedades nativas). Para ello se utilizaron datos y mapas de García, y CONABIO (1998) escala 1:1000000; el "software" SIG ARC-INFO, versión 8.0 y el "hardware" SPARCstation, SUN OS, versión 5.5.1 del laboratorio de Sistemas de Información Geográfica del INIFAP. the effect of temperature of its origin site in plant phenology. Plants grown in Chapingo at early July, had short cycle (100-100 days), were collected in very cold regions where the average annual minimum temperature can drop to -2 ${ }^{\circ} \mathrm{C}$, and the late (110-120 days) in areas where the annual mean minimum temperature rises from 2 to $4{ }^{\circ} \mathrm{C}$ (Vargas et al., 2011).

Each species has in its life cycle a minimum temperature below which does not grow, an optimum temperature at which it grows to its maximum rate, and a maximum temperature above which will not grow and even die. The common bean plant can withstand extreme temperatures between 5 and $40^{\circ} \mathrm{C}$ (Masaya and White, 1991). This data is not known in runner bean and has been only indicated that this specie is adapted to temperate climates, below is intended to classify 798 collection sites of landraces according to the occurrence of minimum and maximum temperature in such environments. It uses the annual mean minimum temperature and maximum annual mean without specifying the months or seasons of the year due to the diversity of environments that in turn originates a large number of data to be analyzed. Thus only makes the first approach to.

\section{Materials and methods}

It was determined the locality and municipality, state or federal entity, altitude, annual precipitation, annual mean minimum temperature and annual mean maximum temperature from the collection sites of 978 accessions of the cultivated form of runner bean (landraces varieties). For this data and maps from García and CONABIO were used (1998) 1:1 000000 scale, the "software" GIS ARC-INFO, version 8.0 and the "hardware" SPARCstation, SUN OS, Version 5.5.1 of the Laboratory of Geographic Information Systems from INIFAP.

Altitude ranges were established with amplitude of $500 \mathrm{~m}$ and precipitation with and amplitude of $500 \mathrm{~mm}$. Accessions were classified by groups according to the occurrence of minimum and maximum annual mean temperature from the collection sites and counted the number of accessions within each group. Correlation analyses were made of the altitude, rainfall, minimum temperature and annual mean maximum temperature from the collection sites with the statistical package SAS (1989). 
Se establecieron rangos de altitud con amplitud de $500 \mathrm{~m}, \mathrm{y}$ de precipitación con amplitud de $500 \mathrm{~mm}$. Se clasificaron por grupos las accesiones de acuerdo a la ocurrencia de temperatura mínimay máxima media anual de los sitios decolectay se contó el número de accesiones dentro de cada grupo. Se hicieron análisis de correlación de la altitud, precipitación, temperatura mínima y temperatura máxima media anual de los sitios de colecta con el paquete estadístico SAS (1989).

\section{Resultados}

Las 798 accesiones fueron colectadas en 140 sitios de 12 estados del territorio nacional: Puebla 65, Tlaxcala 17, México 17, Veracruz 12, Oaxaca 8, Querétaro 5, Chiapas 5, Guanajuato 4, San Luís Potosí 2, Hidalgo 2, Michoacán 2, y Aguascalientes 1.

En general, los resultados concuerdan con Debouck (antes citado) quien señala que el ayocote fue domesticado en las zonas altas y húmedas de México. De los 140 sitios, la mayoría, $80 \%$ tienen altitudes de entre 1500 y $2500 \mathrm{msnm}$, y se cultivan en sitios con una precipitación anual que va desde 300 hasta $4500 \mathrm{~mm}$ lo cual señala la amplia adaptación de la especie a diversos ambientes de humedad (Figuras 1 y 2). La correlación entre la precipitación y la altura sobre el nivel del mar de los sitios de colecta fue de -0.47 que indica tendencia a mayor humedad en los sitios bajos.

Asimismo, en un año la temperatura mínima (nocturna) en dichos sitios va desde -5 hasta $9^{\circ} \mathrm{C}$; y la temperatura máxima (diurna) va desde 21 hasta $37^{\circ} \mathrm{C}$. Estudios anteriores han señalado que $P$. coccineus podría considerarse una especie tolerante tanto a condiciones frías como cálidas, lo que podría explicar su capacidad de distribución en casi todos los tipos climáticos del país (López- Soto, et al., 2005).

La correlación entre altitud y temperatura mínima media anual fue de -0.66; y de altitud con temperatura máxima media anual de -0.43 . Por lo que en estos sitios, la disminución de temperatura no se debe sólo a una mayor altitud. Sino también, aunque en menor media, a la latitud y topografía de dichos sitios.

Dada la amplitud de los rangos de temperatura mínima y máxima que ocurre en un año, inferimos la posible existencia de plasticidad fenológica en las plantas de esta colección como respuesta a la temperatura.

\section{Results}

The 798 accessions were collected at 140 sites in 12 states of the country: 65 Puebla, Tlaxcala 17, Mexico 17, Veracruz 12, Oaxaca 8, Querétaro 5, Chiapas 5, Guanajuato 4, San Luis Potosí 2, Hidalgo 2, Michoacán 2 and Aguascalientes 1.

In general, the results agree with Debouck (cited above) who notes that the runner bean was domesticated in the highlands and humid areas of Mexico. Of the 140 sites, the majority, $80 \%$ have altitudes between 1500 and 2500 masl,andaregrowninareas with an annual rainfall ranging from 300 to $4500 \mathrm{~mm}$ which indicates the wide adaptation of the species to diverse environments moisture (Figures 1 and 2). The correlation between rainfall and the height above sea level of the collecting sites was -0.47 indicating tendency to higher moisture in the lower sites.

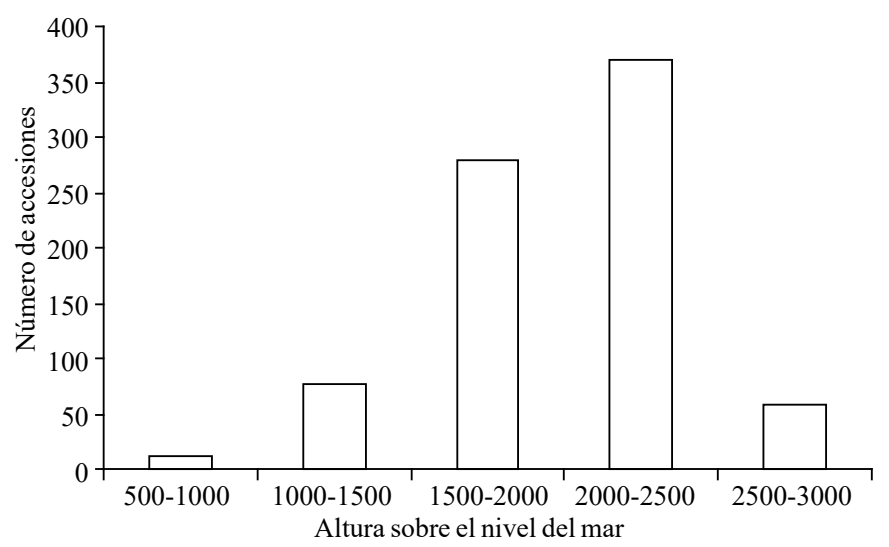

Figura 1. Altitud de 140 sitios de colecta de 798 accesiones de frijol ayocote.

Figure 1. Altitude of 140 collection sites from 798 runner bean accessions.

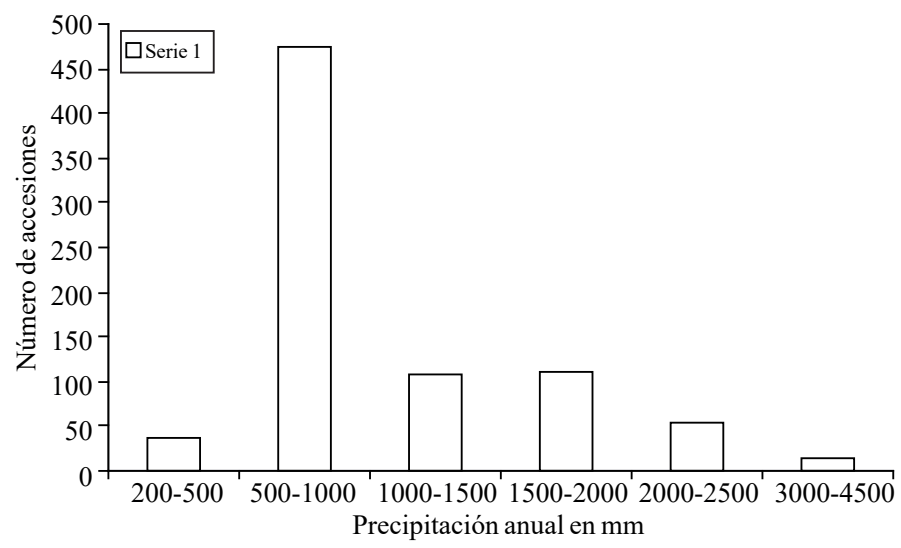

Figura 2. Precipitación anual de 140 sitios de colecta de 798 accesiones de frijol ayocote.

Figure 2. Annual precipitation of 140 collection sites from 798 runner bean accessions. 


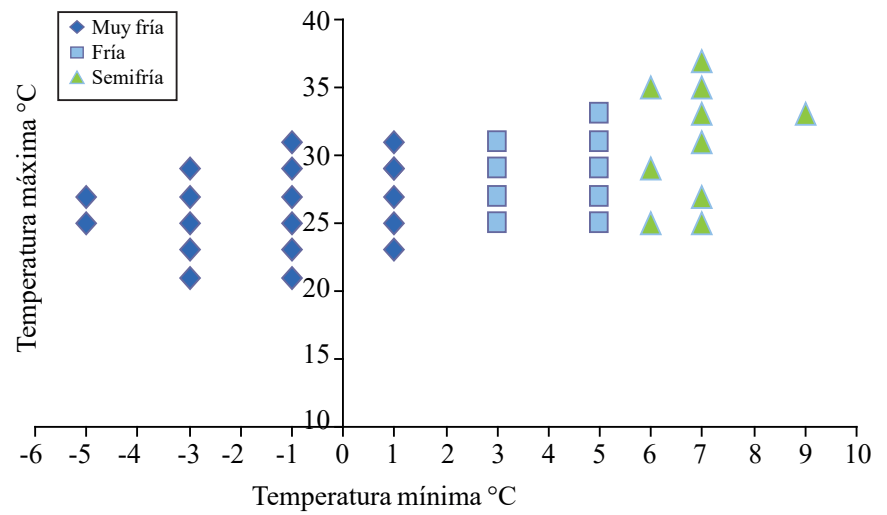

Figura 3. Temperatura mínima media anual y máxima media anual de sitios de colecta de 798 variedades nativas de frijol ayocote en México.

Figure 3. Annual mean minimum temperature and maximum mean from 798 collection sites of runner bean landraces in Mexico.

Para facilitar la comprensión de las características climáticas de los 140 sitios donde ha evolucionado y domesticado el frijol ayocote de la colección, éstos sitios se clasificaron de acuerdo a la ocurrencia de temperatura mínima o de la noche en tres grupos: muy fríos, de $1 \mathrm{a}-5^{\circ} \mathrm{C}$; fríos, de 1 a $5{ }^{\circ} \mathrm{C}$; y semifríos, de 5 a $9{ }^{\circ} \mathrm{C}$ (Figura 3). Los cuales a su vez se subdividieron en cuatro, dos y tres subgrupos respectivamente. Así los muy fríos de subdividieron en sitios con una temperatura mínima de $-5,-3,-1$ y $1{ }^{\circ} \mathrm{C}$; los fríos en 3 y $5{ }^{\circ} \mathrm{C}$, y los semifríos en 6,7 y $9^{\circ} \mathrm{C}$ (Figura 4$)$.
Also, in one year the minimum temperature (night) at these sites ranges from -5 to $9{ }^{\circ} \mathrm{C}$, and the maximum temperature (day) ranges from 21 to $37{ }^{\circ} \mathrm{C}$. Previous studies have indicated that $\mathrm{P}$. coccineus could be considered a tolerant species both cold and warm conditions, which could explain its distribution capacity in nearly every country's climatic types (López-Soto et al., 2005).

The correlation between altitude and annual mean minimum temperature was -0.66 and altitude with annual mean maximum temperature of -0.43 . So in these sites, the temperature decrease is due not only to a higher altitude; but also, to a lesser mean, to latitude and topography of such sites.

Given the amplitude of the range of minimum and maximum temperature that occurs in a year, was inferred the possible existence of phenological plasticity in plants of this collection in response to temperature.

To facilitate the comprehension of climatic characteristics of the 140 sites where it has evolved and domesticated runner bean from the collection, these sites were classified according to the occurrence of minimum temperature or night into three groups: very cold, from 1 to $-5^{\circ} \mathrm{C}$, cold, from 1 to $5{ }^{\circ} \mathrm{C}$, and semi cold, from 5 to $9{ }^{\circ} \mathrm{C}$ (Figure 3 ). Of which in turn were sub divided into four, two and three sub-groups respectively. So the very cold were subdivided

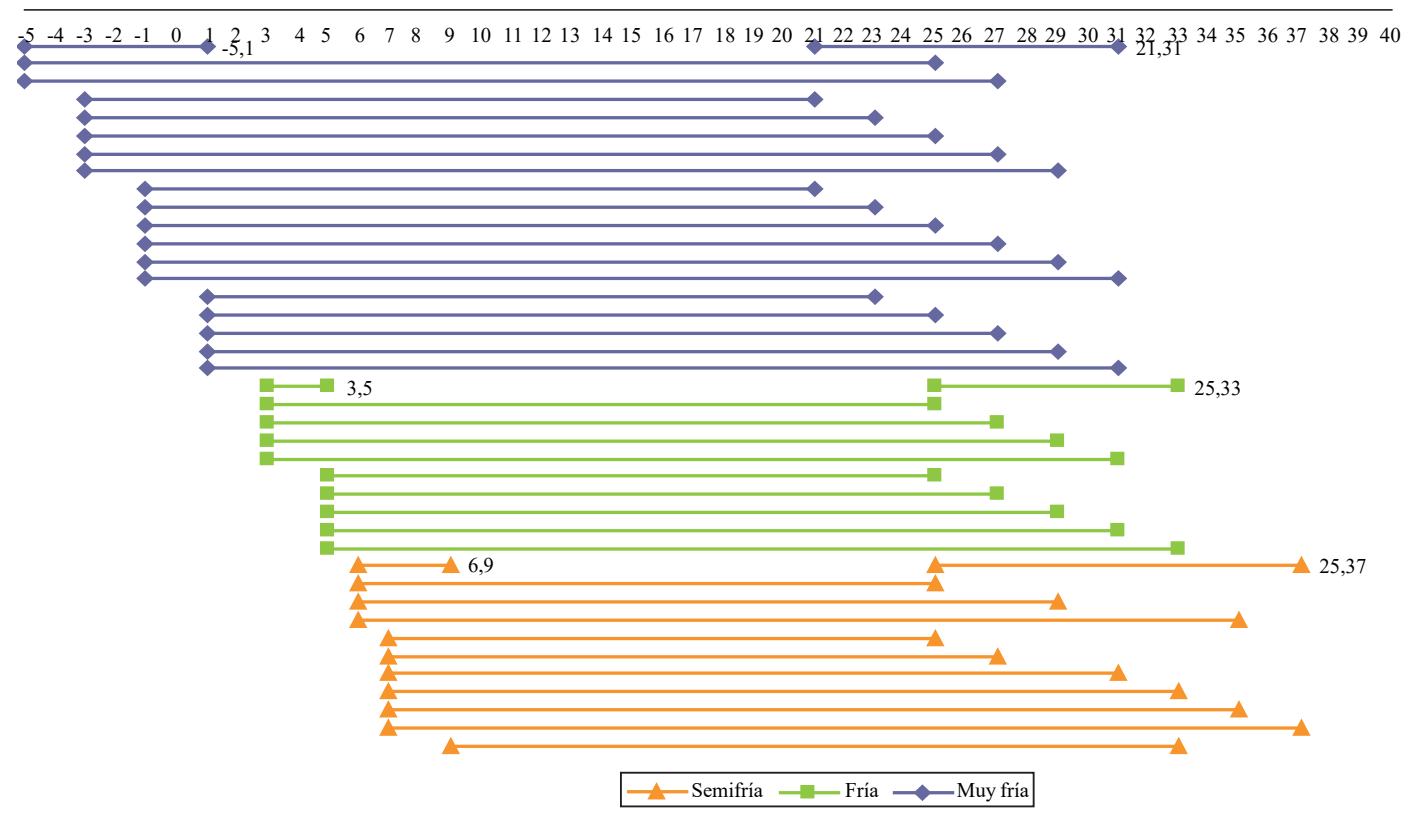

Figura 4. Clasificación de 140 sitios de colecta de frijol ayocote por su temperatura mínima media anual y máxima media anual. Figure 4. Classification of 140 collection sites of runner beans by its minimum annual mean and maximum annual mean temperature. 
Sitios muy fríos. Más de la mitad de los sitios (567) tienen temperatura mínima o de la noche de -5 a $1{ }^{\circ} \mathrm{C}$ y temperatura máxima o del día de 21 hasta $31^{\circ} \mathrm{C}$. Dentro de este rango se distinguen cuatro subgrupos: 10 accesiones de sitios con $-5^{\circ} ; 98$ accesiones de sitios con $-3^{\circ} ; 298$ accesiones de sitios con $-1{ }^{\circ} \mathrm{C}$; y 161 accesiones de sitios con $1{ }^{\circ} \mathrm{C}$. Éstas son muy bajas temperaturas incluso para especies de zonas templadas. No obstante, la adaptación genética a las temperaturas mas frías asociadas a grandes altitudes mejora la resistencia a heladas y el daño por heladas puede minimizarse si la exposición al frío es lenta y gradual, pero la exposición repentina a temperaturas cercanas a cero grados ciertamente producirán daño (Taiz y Zeiger, 1991). En el ayocote el consumo de sus semillas tiernas permite expandir el cultivo hacia altitudes mayores porque la raíz carnosa produce un segundo crecimiento después de heladas ligeras (Debouck, 1997).

La amplia distribución de temperatura diurna permitió separar las accesiones en tres grupos: 16 con temperatura semicálida $\left(21^{\circ} \mathrm{C}\right) ; 284$ cálida $\left(23\right.$ y $\left.25^{\circ} \mathrm{C}\right)$; y 267 muy cálida (de 27 a $31^{\circ} \mathrm{C}$ ). Aunque en la mayoría de éstos sitios la temperatura mínima baja a menos de 0 grados, la máxima llega a ser cálida e incluso muy cálida (Figura 2). Las diferencias entre temperatura del día y la noche fueron de 22 hasta $32{ }^{\circ} \mathrm{C}$. La ocurrencia de lluvia en estos sitios muy fríos varió de 200 hasta $2500 \mathrm{~mm} \mathrm{de}$ precipitación anual. Éstos sitos se localizan en 86 localidades de 12 estados del centro del territorio mexicano (Cuadro 1).

Sitios fríos. 150 accesiones vienen de sitios con temperatura nocturna fría (de 1 hasta $5^{\circ} \mathrm{C}$ ) y de éstas se formaron tres subgrupos: 10 accesiones de sitios con 1 ${ }^{\circ} \mathrm{C}$; 36 accesiones de sitios con $3{ }^{\circ} \mathrm{C}$; y 104 accesiones de sitios con $5{ }^{\circ} \mathrm{C}$.

La temperatura diurna separó las accesiones como sigue: 148 vienen de sitios con temperatura diurna muy cálida (de 27 a $33^{\circ} \mathrm{C}$ ) y sólo dos de sitios con temperatura diurna cálida $\left(25^{\circ} \mathrm{C}\right)$. Las diferencias de temperatura entre el día y la noche en este grupo fueron de 20 hasta 28 grados. La ocurrencia de lluvia en estos sitios varió de 550 hasta $4250 \mathrm{~mm}$ de precipitación al año. Los sitios con mayor precipitación anual fueron La Cortadura, Zoquiapan y Cuetzalan, Puebla de clima semicálido subhúmedo con lluvias todo el año. into sites with a minimum temperature of $-5,-3,-1$ and 1 ${ }^{\circ} \mathrm{C}$; the cold in 3 to $5{ }^{\circ} \mathrm{C}$, and the semi cold in 6,7 and 9 ${ }^{\circ} \mathrm{C}$ (Figure 4).

Very cold sites. More than half of the sites (567) have a minimum temperature or overnight at -5 to $-1{ }^{\circ} \mathrm{C}$ and maximum temperature or day from 21 to $31^{\circ} \mathrm{C}$. Within this range there are four subgroups: 10 accessions of sites with $-5^{\circ} ; 98$ accessions of sites with $-3^{\circ} ; 298$ accessions of sites with $-1{ }^{\circ} \mathrm{C}$, and 161 accessions of sites with $1{ }^{\circ} \mathrm{C}$. These are very low temperatures even for temperate species. However, genetic adaptation to colder temperatures at high altitudes improves resistance to freezing and frost damage can be minimized if the exposure to cold is slow and gradual, but sudden exposure to temperatures close to zero degrees certainly will produce damage (Taiz and Zeiger, 1991). In runner beans the consumption of its tender seeds allows to expand the cultivation towards higher altitudes because the fleshy root produces a second growth after light frosts (Debouck, 1997).

The wide distribution of diurnal temperature allowed separating the accessions into three groups: 16 with semi warm temperature $\left(21^{\circ} \mathrm{C}\right) ; 284$ warm $\left(23\right.$ to $\left.25^{\circ} \mathrm{C}\right)$ and 267 very warm $\left(27-31^{\circ} \mathrm{C}\right)$. Although most of these sites the minimum temperature falls below 0 degrees, the maximum becomes warm and even very warm (Figure 2 ). Temperature differences between day and night were 22 to $32{ }^{\circ} \mathrm{C}$. The occurrence of rain on these very cold sites ranged from 200 to $2500 \mathrm{~mm}$ of annual precipitation. These sites are located in 86 locations of 12 states of central Mexico (Table 1).

Cold sites. 150 accessions come from sites with cool night temperatures (from 1 to $5^{\circ} \mathrm{C}$ ) and from these three subgroups were formed: 10 sites accessions with $1^{\circ} \mathrm{C} ; 36$ sites accessions with $3{ }^{\circ} \mathrm{C}$, and 104 site accessions with $5^{\circ} \mathrm{C}$.

The daytime temperature separated the accessions as follows: 148 come from sites with very warm daytime temperatures $\left(27\right.$ to $33{ }^{\circ} \mathrm{C}$ ) and only two sites with warm daytime temperatures $\left(25^{\circ} \mathrm{C}\right)$. The temperature differences between day and night in this group were 20 to 28 degrees. The occurrence of rain at these sites ranged from 550 to $4250 \mathrm{~mm}$ of precipitation per year. The highest annual rainfall sites were La Cortadura, Zoquiapan and Cuetzalán, Puebla with semi warm sub humid climate with precipitation all year. 
Cuadro 1. Localidades o municipios de sitos de colecta de frijol ayocote muy fríos (temperatura mínima media anual de 1 hasta $-5^{\circ} \mathrm{C}$ ) y amplio rango de ocurrencia de precipitación.

Table 1. Towns and municipalities of collection sites very cold of runner bean (annual mean minimum temperature from 1 to $-5^{\circ} \mathrm{C}$ ) and wide range of precipitation occurrence.

\begin{tabular}{|c|c|c|}
\hline $\begin{array}{lr}\text { Precipitación en Frecuencia } \\
\text { mm al año }\end{array}$ & Localidad o Municipio & Estado \\
\hline De 200 a 500 & $\begin{array}{l}\text { Zacapoaxtla, Tehuacan } \\
\text { Moctezuma, Charcas } \\
\text { San Luís }\end{array}$ & $\begin{array}{l}\text { Puebla } \\
\text { San Luís Potosí } \\
\text { Guanajuato }\end{array}$ \\
\hline
\end{tabular}

De 500 a $1000 \quad 331$

Aguascalientes

Aguascalientes

Los Reyes, Cuautitlán, Huehuetoca, La Purificación, Tultepec, Zumpango, México

Jilotepec, Toluca, Cuautitlan, Yanhuitlan Oaxaca

La Dieta

Michoacán

Tepeaca, Cholula, Cd. Serdán, Xanacatlán, Xautla, San Isidro, Acajete, Puebla San Diego, Tepatlaxco, Zacapoaxtla, Huejotzingo, Puebla, Amozoc, Tlaltenango, San Matías, Cuazayotla, Cuichayatla, Esperanza, Palmar, San Mateo

Querétaro

La Griega, Tlatlauquitepec, Teteles,

San Juan del Milagro

Tlaxcala

San Matías, San Damián, Villa Alta, San Cosme, Xalostoc, Ixtenco, San

Jorge, San Juan Totolac, El Carmen, Zacatelco, Tlaxcala, San Matías, Guanajuato

Cocoyotla, Nanacamilpa

Hidalgo

Dolores,

Veracruz

Huichapan,

Perote

De 1000 a $1500 \quad 64$

San Juan Chamela

Chiapas

San José Villa de Allende, Villa Guerrero

México

Atlautla, Xayacatlan, Zacatlán,

Puebla

Xochiapulco, Zacapoaxtla

Veracruz

Toxtlacuaya, Altotonga, Jalapa

De 1500 a $2000 \quad 109$

Zacapoaxtla, San Salvador Chachapa, San Isidro Toltepec, Teziutlan, Puebla Xochiapulco, Atempan,

Tlatlauquitepec, Las Lomas

Veracruz

Jalacingo

Chiapas

Tenejapa

Puebla

Tlatlauquitepec, San Isidro Toltepec, Teteles

De 2000 a $2500 \quad 28$

Plan de Gpe. Tlaltoqui, Zacapoaxtla, Nauzontla, Acayotitlan

Puebla 
Cuadro 2. Localidades o municipios de sitos de colecta de frijol ayocote fríos (temperatura mínima media anual de 1 hasta $5^{\circ} \mathrm{C}$ y muy amplio rango de ocurrencia de precipitación.

Table 2. Towns and municipalities from collection sites of cold runner beans (minimum annual mean temperature from 1 to $5^{\circ} \mathrm{C}$ ) and very wide range of precipitation.

\begin{tabular}{|c|c|c|c|}
\hline Precipitación en mm al año & Frecuencia accesiones & Localidad y Municipio & Estado \\
\hline De 500 a 1000 & 106 & $\begin{array}{l}\text { Cuilapan de Guerero, San Juan Chilateca, } \\
\text { Ocotlan, Huajapan, Oaxaca, } \\
\text { Zapotitlan, Xautla, Tepeaca, Atlixco } \\
\text { Zumpango, Jilotepec, } \\
\text { Comitan } \\
\text { Acultzingo }\end{array}$ & $\begin{array}{l}\text { Puebla } \\
\text { México } \\
\text { Chiapas } \\
\text { Veracruz }\end{array}$ \\
\hline DE 1000 a 1500 & 11 & $\begin{array}{l}\text { Tepoxtepec Tenancingo, } \\
\text { La Mesa }\end{array}$ & $\begin{array}{l}\text { México } \\
\text { Michoacán }\end{array}$ \\
\hline De 1500 a 2000 & 8 & Cd. Mendoza & Veracruz \\
\hline De 2000 a 2500 & 15 & $\begin{array}{l}\text { Nauzontla, Buena Vista, Ahuacatlan, } \\
\text { Puebla, Cd. Serdan, Tequila }\end{array}$ & Veracruz \\
\hline De 3000 a 3500 & 5 & La Cortadura (Viene de Zoquiapan) & Puebla \\
\hline De 4000 a 4500 & 5 & Cuetzalan & Puebla \\
\hline
\end{tabular}

Sitios semifríos. Sólo 78 accesiones vienen de sitios semifríos con temperatura de la noche de 5 a $9{ }^{\circ} \mathrm{C}$ y temperatura del día entre 25 y $37^{\circ} \mathrm{C}$. Éstas se dividieron en cuatro subgrupos: tres accesiones de sitios con $5^{\circ} \mathrm{C}, 41$ accesiones de sitios con $6^{\circ} \mathrm{C}, 33$ accesiones de sitios con 7 ${ }^{\circ} \mathrm{C}$, y una accesión de un sitio con $9{ }^{\circ} \mathrm{C}$.

La mayoría de estos sitios (70 accesiones) tienen una temperatura diurna muy cálida de entre 27 y $37^{\circ} \mathrm{C}$, y sólo 8 accesiones vienen de sitios cálidos con temperatura diurna de $25^{\circ} \mathrm{C}$. Al igual que en los sitios fríos, las diferencias de temperatura entre el día y la noche fueron de 20 a 28 grados.
Semi cold sites. Only 78 accessions come from semi cold sites with night temperature of 5 to $9{ }^{\circ} \mathrm{C}$ and day temperature between 25 and $37{ }^{\circ} \mathrm{C}$. These were divided into four subgroups, three accessions of sites with $5^{\circ} \mathrm{C}, 41$ accessions of sites with $6^{\circ} \mathrm{C}, 33$ accessions of sites with $7^{\circ} \mathrm{C}$, and an accession of site with $9{ }^{\circ} \mathrm{C}$.

Most of these sites ( 70 accessions) have very warm daytime temperatures between 27 and $37^{\circ} \mathrm{C}$, and only 8 accessions come from warm places with daytime temperature of $25^{\circ} \mathrm{C}$. As in cold places, the temperature differences between day and night were 20 to 28 degrees.

Cuadro 3. Localidades o municipios de sitos de colecta de frijol ayocote semifríos (temperatura mínima media anual de 5 hasta $9^{\circ} \mathrm{C}$ ) y amplio rango de ocurrencia de precipitación.

Table 3. Towns and municipalities from collection sites of semi cold runner beans (minimum annual mean temperature 5-9 ${ }^{\circ} \mathrm{C}$ ) and wide range of precipitation.

\begin{tabular}{|c|c|c|c|}
\hline Precipitación en mm al año & Frecuencia accesiones & Localidad o Municipio & Estado \\
\hline$<500$ & 3 & Ajalapan & Puebla \\
\hline De 500 a 1000 & 30 & $\begin{array}{l}\text { Acatlan, Cuazayotla, } \\
\text { Tlatonqui, Plan de Guadalupe, San Lucas } \\
\text { El Grande, Matamoros, y Acteopan }\end{array}$ & Puebla \\
\hline De 1000 a 1500 & 32 & $\begin{array}{l}\text { Gutiérrez Zamora, } \\
\text { Las Vigas, Jalapa } \\
\text { Temascaltepec }\end{array}$ & $\begin{array}{l}\text { Veracruz } \\
\text { México }\end{array}$ \\
\hline De 2000 a 2500 & 10 & $\begin{array}{l}\text { Artalapa, Solistiahuacan } \\
\text { Santa María La Asunción }\end{array}$ & $\begin{array}{l}\text { Chiapas } \\
\text { Oaxaca }\end{array}$ \\
\hline
\end{tabular}




\section{Conclusiones}

La distribución de variedades criollas de frijol ayocote colectadas en el centro-sur del territorio mexicano permitió agrupar los sitios de domesticación de acuerdo a la ocurrencia de temperatura y precipitación.

La domesticación se llevó a cabo principalmente en zonas altas, frías y húmedas, aunque también existen algunos materiales desarrollados en zonas bajas, cálidas y con poca precipitación.

La clasificación aquí presentada permitirá en futuros estudios dilucidar: 1) la respuesta fenológica de la planta a la temperatura ambiente; 2) la relación entre los tipos de hábito de crecimiento del ayocote y el clima de su lugar de origen; y 3) la relación entre la temperatura de la noche y el desarrollo de la raíz carnosa de la planta, ya que se infiere que las variedades que tienden a la perennidad son aquellas de raíz carnosa domesticada en sitios muy fríos y que dicha raíz es una estrategia evolutiva de la planta para sobrevivir en un ambiente adverso.

\section{Agradecimientos}

La autora principal y coautores agradecen el financiamiento para este trabajo por parte del Servicio Nacional de Inspección y Certificación de Semillas- Sistema Nacional de Recursos Genéticos para laAlimentación y la Agricultura y del Instituto Nacional de Investigaciones Forestales, Agrícolas y Pecuarias.

\section{Literatura citada}

Bataillon, C. 1993. Las regiones geográficas en México. 10ª (Ed.). Trad. del francés. Siglo XXI editores. México, D.F. 23-31 pp.

Debouck, D. G. 1994. Beans (Phaseolus spp.). In: neglected crops: 1492 from a different perspective. Hernándo, B. J. E. and León, J. (Eds.). Plant production and protection series 26. FAO. Rome, Italy. www.hort.purdue.edu/newcrop/1492/beans.html.

Debouck, D. G. 1997. La agricultura en mesoamérica: frijoles (Phaseolus spp.). In: cultivos andinos subexplotados y su aporte a la alimentación. Tapia, M. E. (Ed.). ONU-FAO, Santiago, Chile. www.rlc.fao.org/es/agricultura/produ/cdrom/contenido/ libro10/cap01.htm.

\section{Conclusions}

The distribution of landraces varieties of runner beans collected in the south-central Mexican territory allowed domestication sites to be grouped according to temperature and precipitation occurrence.

Domestication took place mainly at high altitudes, cold and wet zones, although there are some materials developed in lowlands, warm with little precipitation.

The classification presented here in future studies will elucidate: 1) plant phenological response to temperature, 2) relationship between types of growth habit from runner beans and climate of their place of origin, and 3) the relationship between temperature at night and fleshy root development of the plant, since is inferred that the varieties that tend to perennial are those fleshy roots domesticated in very cold sites and that such root is a plant evolutionary strategy to survive in an adverse environment.

End of the English version

Freytag, G. F. and Debouck, D. G. 2000. Taxonomy, distribution, and ecology of the genus Phaseolus (LeguminoseaePapilionoideae) in North America, Mexico and Central America. Botanical Research Institute of Texas (BRIT) Press. Fort Worth, Texas, USA. 50-61 pp.

García, E. y Comisión Nacional para el Uso de la Biodiversidad (CONABIO). 1998. Precipitación total anual: escala 1:1000000. México. www.conabio.gob.mx.

García, E. y Comisión Nacional para el Uso de la Biodiversidad (CONABIO). 1998. Temperatura máxima promedio: escala 1:1000000. México. www.conabio.gob.mx.

García, E. y Comisión Nacional para el Uso de la Biodiversidad (CONABIO). 1998. Temperatura mínima promedio: escala 1:1000000. México. www.conabio.gob.mx.

Hernández X, E.A.; Ramos, R. y Martínez,A. M.A. 1979. Etnobotánica. In: contribuciones al conocimiento del frijol (Phaseolus) en México. Engleman, M. (Ed.). Colegio de Postgraduados, Chapingo, Texcoco, Estado de México. 321-333 pp.

López, S. J. L.; Ruíz, C. J. A.; Sánchez, G. J. J. y Lépiz, I. R. 2005. Rev Fitotec. Mex. 28(3):221-230.

Masaya, P. and White, J. W. 1991. Adaptation to photoperiod and temperature. In: common beans. Research for crop improvement. Schoonhoven, A. V. and Voysest, O.(Eds.). CAB Int. U.K. and CIAT, Cali, Colombia. 445-500 pp.

Miller, E. V. 1967. Fisiología vegetal. Trad. de inglés al español Latorre, F. Unión tipográfica. Editorial Hispano Americana. Primera edición. México. 252-253 pp. 
Miranda, C. S. 1978. Evolución de Phaseolus vulgaris y P. coccineus. In: contribuciones al conocimiento del frijol. Engleman, M. (Ed.). Colegio de Postgraduados, Chapingo, Estado de México. 83-99 pp.

Rzedowski, G. C. de y Rzedowski, J. 2001. Flora fanerogámica del Valle de México. $2^{\text {da }}$ (Ed.). Instituto de Ecología, A. C. y Comisión Nacional para el Conocimiento y Uso de la Biodiversidad (CONABIO). Pátzcuaro, Michoacán. 306-307 pp.

Salisbury, F. B. and Ross, L. W. 1985. Plant physiology. Wads Worth Publishing Co. Belmont, CA., USA.419-425 pp.

Santamaría, F. J. 2005. Diccionario de mejicanismos. Porrúa, México, D. F. 102 pp.
Statistical Analysis System(SAS) Institute Inc. 1989. Statistical Analysis System, version 6.03. Cary, NC, USA.

Taiz, L. and Zeiger, E. 1991. Plant physiology. The Benjamin/Cummings Publishing Co. Redwood City, California, USA. 356 p.

Vidal, Z. R. 2005. Las regiones climáticas de México. Temas selectos de Geografía de México. Instituto de Geografía - Universidad Autónoma de México (UNAM). México, D. F. 212 p.

Vargas, V. P.; Muruaga, M. J.; Martínez, V. S.; Ruiz, S. R.; Hernández, D. S. y Mayek, P. N. 2011. Diversidad morfológica del frijol ayocote del Carso Huasteco de México. Universidad Autónoma de México (UNAM). Rev. Mex. Biod. 82:767775 . 